\title{
COMPETÊNCIA EM SEDE DE INVESTIGAÇÃo Preliminar: há Prejuízos ho Processo?
}

Alessandro Maciel Lopes

Departamento de Polícia Federal

$$
\text { ○浆方 }
$$

\begin{abstract}
RESUMO
Trata-se de breve pesquisa para analisar a adequação do uso da expressão "competência" à atividade de investigação preliminar e seus reflexos práticos na ação penal. Pretende-se analisar a validade da prova a partir da capacidade do agente que produz a investigação e formalização de seus atos.
\end{abstract}

Palavras-Chave: Investigação preliminar. Competência. Atribuição. Validade. Provas.

\section{INTRODUÇÃ̃o}

É recente a preocupação da doutrina com a investigação preliminar. Até há pouco, os estudos sobre inquérito policial se limitavam, quando muito, a um capítulo nos manuais de Direito Processual Penal. Mas ainda são poucas, bem poucas, as obras sérias a respeito do tema.

Supostamente, a prescindibilidade do inquérito para a propositura da ação penal e a falsa premissa de que os vícios nele produzidos não alcançariam o processo relegou sua importância dentro do sistema acusatório. Contudo, e curiosamente, não são isoladas as condenações que se fundam quase que exclusivamente nos elementos obtidos na fase pré-processual.

Ao falar de sistema acusatório devemos contextualizá-lo num sentido amplo, em seu caráter democrático, não se limitando à etiquetação de atos ou fases do processo. A classificação simplista e estanque de estágios processuais não contribui para a análise crítica do processo. É por demais ingênuo (e inútil) qualificar o sistema processual brasileiro como misto rotulando-se as fases da persecução a partir de premissas medievas. A fase preliminar do 
processo, na qual se investiga para buscar elementos indicadores de materialidade e autoria, tem caracteres próprios que não são admitidos na ação penal. Mas isso não lhe frustra a necessidade de estar alinhada e adequada ao modelo acusatório. É por demais confortante classificar a fase preliminar como modelo inquisitivo e admitir, em decorrência disso, que vícios aí originados não alcancem a ação penal.

A investigação preliminar carece de estudo crítico, assim como carece de regulamentação. Rito e forma são instrumentos de garantia do acusado não apenas na ação penal, mas também na fase investigatória. $\mathrm{O}$ inquérito policial tem traços mínimos de rito e forma estabelecidos no Código de Processo Penal. Mas o próprio código prescinde do inquérito para a propositura da ação penal e não estabelece os preceitos mínimos para a investigação promovida em procedimento diverso. E sequer exige procedimento.

Ao tratar do inquérito policial o Código de Processo Penal traz elementos que fornecem o esteio elementar de formalidade: instauração, registro, autuação, prazo de conclusão, controle externo (judicial e ministerial), impossibilidade de arquivamento pelo órgão que instaurou e impossibilidade de desarquivamento sem novas provas.

Se é certo que essa regulamentação é insuficiente, também é certo que a sua supressão é mais nefasta. Por esta razão, devemos marcar aqui um ponto crucial de dissonância na investigação criminal: investigação formal e informal. A formal há de ser considerada aquela que possui forma - ainda que elementar - definida em lei. A contrario sensu, informal, a investigação que não guarda qualquer parâmetro de forma, conteúdo ou controle legalmente estabelecido.

Cremos que esse deva ser o ponto de partida da investigação preliminar. Forma é garantia. Para Auary Lopes Jr. e Ricardo Jacobsen Gloeckner (2013) a instrumentalidade é nota predominante da investigação preliminar , com objetivo imediato de garantir o eficaz funcionamento da Justiça e instrumentalizar a própria pretensão acusatória . Nereu José Giacomolli aponta o caráter dúplice da investigação preliminar: função de viabilizar e, ao mesmo tempo, impedir o exercício da ação penal, fornecendo elementos importantes às interferências incisivas na esfera dos direitos fundamentais do sujeito. (GIACOMOLLI, 2011) 
Isso porque não há como admitir uma investigação instrumentalizada - que autoriza ou impede o exercício da ação penal - se não realizada de forma concatenada e lógica (LOPES et al., 2013) e de acordo com o rito definido em lei. Retirar a forma instrumental da investigação significa abrir uma janela à prática de abusos e fechar a porta ao exercício da defesa.

Para Danielle Souza de Andrade e Silva Cavalcanti (2011) a obediência às formas procedimentais predeterminadas em lei é o mecanismo para pôr freio às atividades arbitrárias na fase procedimental ${ }^{1}$.

E se a forma é algo relevante e inafastável, os envolvidos na investigação e sua esfera de atuação se constituem, também, em elementos fundamentais ao exercício da investigação. A fase preliminar não possui partes, senão meros sujeitos (LOPES et al., 2013) e, em regra, seus dirigentes não são - ou não deveriam ser - os mesmos que atuam no processo.

\section{CompetênCia OU Atribuição para Investigar?}

Até o advento da Lei $\mathrm{n}^{\circ} 10.446 / 02$, não havia norma tratando especificamente de esferas de atribuição ou competência na fase investigatória. Ainda hoje ela é ignorada por não se saber quais seriam as consequências decorrentes de seu descumprimento. Ignorância que tem origem na negligência da doutrina com a investigação preliminar, que relega os problemas decorrentes de seus vícios "como se esse não fosse um problema fundamental a ser resolvido" 2 , nas precisas palavras de Erica de Oliveira Hartmann (2008, p. 289).

Falar em competência quando o tema é investigação soa como uma heresia no meio jurídico.

1 A investigação preliminar nos delitos de competência originária dos tribunais, p. 179. Faz referência a Luigi Ferrajoli, para quem a ritualidade dos procedimentos estaria inserida entre as "garantias das garantias", as denominadas sobregarantias processuais.

2 Ao tratar de nulidade no inquérito policial, assim se manifesta: "Já há algum tempo fala-se, embora muito pouco, sobre o problema dos vícios existentes na investigação preliminar, primeira fase da persecução penal. A doutrina tradicional do Direito Processual Penal praticamente nada fala sobre isso, como se não fosse problema fundamental a ser resolvido. Em verdade, a se perquirir sobre o tema, não só se questiona sobre a possibilidade ou impossibilidade de reconhecer vícios no Inquérito Policial (forma mais comum de investigação preliminar), mas se constata que sequer o tema dos vícios dos atos praticados pelos órgãos do Estado ou pelas partes na esfera criminal é tratado de maneira decente desde o ponto de vista teórico, o que dificulta mais ainda encontrar uma saída factível, democráticoconstitucional, para a questão que ora se põe.” 
Assim como o órgão investigador não teria jurisdição, mas apenas circunscrição, não seria correto falar "competência”, mas “atribuição”. Essa a leitura feita por parte da doutrina. Dela resulta um senso comum proibitivo de utilizar a expressão "competência", o qual condena silentemente quem a profere. É como se ela desvelasse uma boçalidade jurídica representada no grave erro técnico-semântico.

De fato, há uma série de expressões e neologismos jurídicos carecedores de técnica linguística e metodológica. Esses apelidos são criados, difundidos, repetidos e chegam a adquirir a condição de verdades dogmáticas. Não raro, ganham status de princípio ou norma. É inegável que certas expressões trazem em si forte apelo semiótico. Mas violam prejudicialmente a coerência do sistema e da argumentação jurídica. Dentre vários exemplos existentes, podemos lembrar o "crime anão", o "homem médio", o "sursis processual” ", o "juiz leigo", o princípio dos sujeitos "naturais" ("promotor natural"5, "defensor natural"6, "delegado natural"7), o "princípio in dubio pro societate", o "princípio da confiança" como princípio geral de direito penal", do "princí-

3 Utilizando a expressão "sursis processual": JESUS, Damásio Evangelista de. Lei dos Juizados Especiais Criminais Anotada. 12a ed. São Paulo: editora Saraiva, 2010, p. 120.

4 Lei no $9.099 / 95$, art. $7^{\circ}$. A figura do juiz leigo só existe no tribunal do júri, onde os jurados são pessoas das mais diversas formações e que não precisam fundamentar suas decisões. A lei 9.099/95 referese, na verdade, ao juiz não togado, já que o chamado "juiz leigo" é alguém que possui tem formação técnica (advogado) e elabora parecer fundado em preceitos jurídicos.

5 Entendo pela existência do princípio do promotor natural: NUCCI, Guilherme de Souza. Manual de processo penal e execução penal. $11^{\text {a }}$ ed. São Paulo: Forense, 2014. P. 76. OLIVEIRA, Eugenio Pacelli de. Curso de Processo Penal. 15a ed. Rio de Janeiro: Lumen Juris, 2011. P. 466. RANGEL, Paulo. Direito Processual Penal. Rio de Janeiro: Lumen Juris, 2008. P. 35. Ainda, voto do Min. Marco Aurélio do STF, proferido no Mandado de Segurança No 33.163/DF

6 Entendendo pela existência da figura do defensor natural: TAVORA, Nestor; ALENCAR, Rosmar Rodrigues. Curso de Direito Processual Penal, p. 68.

7 Entendendo pela existência da figura do delegado natural: CABETTE, Eduardo Luiz Santos. Nova lei 12.830/13 - investigação pelo Delegado de Polícia. Disponível em http://atualidadesdodireito.com. br/eduardocabette/2013/06/23/nova-lei-12-83013-investigacao-pelo-delegado-de-policia/ , acesso em 11/07/14. ARAÚJO, Moacir Martini de. O Princípio do Delegado Natural Com Efetivação do Estado Democrático de Direito. Revista Brasileira de Ciências Policiais, Vol 3, p. 27-41, jan/jun 2012.

8 Consta em decisões do Tribunal de Justiça do Rio Grande do Sul: Recurso em Sentido Estrito ${ }^{\circ}$ 70052244423 (Rel. Rosane Ramos de Oliveira Michels, julgado em 29/07/14), n 70059126235 (Rel. Jayme Weingartner Neto, julgado em 10/07/14), nº 70059915587 (Rel. Diogenes Vicente Hassan Ribeiro, julgado em 10/07/14). Superior Tribunal de Justiça, Habeas Corpus n HC 279802/ ES (Rel. Rogerio Schietti Cruz, julgado em 05/05/14), HC 219625/SP (Rel. Sebastião Reis Junior, julgado em 19/12/13). CAPEZ, Fernando. Curso de Direito Penal I. 16. ed. São Paulo: Editora Saraiva, 2012.651p

9 CAPEZ, Fernando. Curso de Direito Penal I. 16. ed. São Paulo: Editora Saraiva, 2012. P. 651. Também jurisprudência do Tribunal de Justiça do Rio Grande do Sul: apelações nº 70010124980 e nº 70006990634. 
pio da confiança no juiz do processo" ${ }^{10}$, do "princípio da proibição do atalhamento constitucional" ${ }^{11}$, do "princípio da tolerância zero"12, e tantos outros.

Temos no direito pátrio uma forte tendência em adaptar expressões jurídicas consagradas para situações superficialmente similares, Com efeito, criam-se verdadeiras gambiarras linguísticas. Supostamente, essa tendência se dá pela necessidade de simplificar o conhecimento jurídico. Se, didaticamente, essas adaptações são esclarecedoras e se constituem ótimos exemplos comparativos, do ponto de vista jurídico carecem de técnica e não suportam uma análise aprofundada.

A gravidade é quando essas expressões - que não passam de brocardos - ganham eco nos cursos preparatórios, nos manuais e certames públicos, revestem-se de "princípio"13 e, pior, são proferidas pelos "bouche de la loi" como se leis fossem. Com efeito, são jurisprudencialmente (mal) interpretadas e aplicadas à realidade problemático-decidenda. (NEVES, 2003)

Lenio Luiz Streck (2014) combate o conhecimento simplificado e a criação de princípios despidos de normatividade, ao que chama de "pan-principiologismo" . Reputa esse fenômeno como fruto da "cultura manualesca", decorrente da aquisição de conhecimento de baixa densidade científica. Humberto Ávila (2012), no mesmo sentido, critica a eclosão de princípios, a qual denomina de euforia do Estado Principiológico. Como aponta, ela implicaria em exageros e problemas teóricos que inibiriam a própria efetividade do ordenamento jurídico .

No processo penal parte da doutrina convencionou utilizar a expressão "competência" para referir-se exclusivamente ao exercício da jurisdição e "atribuição" quando se tratar de funções não jurisdicionais. Procuramos buscar as origens dessa concepção. Encontramos apenas referências nos manuais, os quais repercutem irrefletidamente que o termo competência seria afeto apenas aos juízes (MIRABETE, 2006) . Não há maiores explicações sobre a origem $^{14}$.

10 TJRS, apelação criminal $\mathrm{n}^{\circ} 70059484386,70058884354,70060289683$

11 LENZA, Pedro. Direito Constitucional Esquematizado, 16a ed, Saraiva, p. 318.

12 Ainda não consta nos manuais de direito penal, mas vários textos na internet já se referem a esse argumento com "princípio".

13 Lenio Streck fala em panprincipiologismo (STRECK, Lenio. Senso Incomum - O panprincipiologismo e o sorriso do lagarto, Conjur). Humberto Ávila em euforia do Estado Principiológico (ÁVILA, Humberto. Teoria dos princípios da definição: à aplicação dos princípios jurídicos. $13^{\mathrm{a}} \mathrm{ed}$. São Paulo: Malheiros, 2012, pág. 27)

14 Fernando Capez explica que o legislador, equivocadamente, refere-se a "jurisdições" no art. $4^{\circ}$ do 
Talvez tenha sido essa cultura que levou a concepção do termo "competência" apenas para atividades jurisdicionais. No entanto não encontramos no discurso jurídico argumentos que o justifiquem.

Por melhor que tenham sido as intenções de buscar técnica à expressão "competência" dentro do sistema jurídico processual brasileiro, nos sentimos no dever de rechaçar a acepção que repele sua aplicação quando se refere à competência investigatória. Por duas razóes, como se exporá a seguir. A primeira, de caráter semântico, analisando a correta significância das expressões. A segunda, de validade prática, onde são examinadas as consequências das validades dos atos praticados por quem não detém competência.

\subsection{Significado JURídico das EXPRESSÕes “ATribuição” E "COMPETÊNCIA"}

No que se refere à semântica, devemos atentar que os vocábulos "atribuição" e "competência", dependendo da acepção, são considerados sinônimos na língua portuguesa ${ }^{15}$. Não obstante, ao vocábulo "competência" são conferidos significados mais específicos, notadamente relacionados à qualidade do agente para a prática de determinado ato ${ }^{16}$.

CPP quando o correto seria falar "circunscrições”, já que a atividade judicante é exclusiva dos juízes. Logo em seguida ele explica que a mesma leitura deve ser feita às expressões competência/atribuição e que por isso, quando se falar em competência para atividades não jurisdicionais, o termo deverá ser sempre tomado em seu sentido vulgar (a expressão "sentido vulgar" é usada, também, por Fernando da Costa Tourinho Filho, como se dirá adiante). Nos parece que a explicação dada por Capez não guarda lógica e coerência, além de estar desprovida de técnica interpretativa, mormente porque a expressão competência possui exatamente essa acepção no direito administrativo e constitucional e não há essa relação simétrica entre jurisdição/competência e circunscrição/atribuição. CAPEZ, Fernando. Curso de Processo Penal. São Paulo: Saraiva, 2006, p. 73-74

15 De acordo com o dicionário Houaiss: atribuição 1. Ato ou efeito de atribuir; 2. Responsabilidade própria de um cargo ou função; competência, prerrogativa. De acordo com o dicionário Michaellis: atribuição. 1. Ação de atribuir. 2. Competência, prerrogativa, privilégio. 3. Responsabilidade inerente a um cargo ou uma tarefa.

16 Definição dada pelo dicionário Houaiss: competência. 1. Rubrica: termo jurídico. Aptidão de uma autoridade pública de efetuar determinados atos. 1.1. Rubrica: termo jurídico. Qualidade legítima de jurisdição ou autoridade, conferidas a um juiz ou a um tribunal, para conhecer e julgar certo feito submetido à sua deliberação dentro de determinada circunscrição judiciária. 1.2. Rubrica: termo jurídico. Poder detido por um indivíduo, em razão do seu cargo ou função, de praticar atos próprios deste ou desta. Definição do dicionário Michaellis: competência. 1. Capacidade legal, que um funcionário ou um tribunal tem, de apreciar ou julgar um pleito ou questão. 2. Faculdade para apreciar e resolver qualquer assunto. 3. Aptidão, idoneidade. 
Atribuição significa responsabilidade inerente a um cargo ou função, enquanto que competência é a capacidade legal, a aptidão para apreciar e resolver determinado assunto. Em que pese a proximidade dos significados que por vezes são sinônimos - poderíamos reputar a competência como uma esfera delimitadora da atribuição. Significaria dizer que não bastaria a um agente público possuir a atribuição para a prática de determinado ato, mas deve contar com a capacidade legal para poder praticá-lo.

É esse, também, o sentido fornecido pelo direito administrativo. Competência, na dogmática administrativista, é um dos elementos essenciais do ato administrativo e que the confere validade (DROMI, 2004). Roberto Dromi define competência como a esfera de atribuições dos entes e órgãos, determinada pelo direito objetivo ou pela lei. Para Maria Sylvia di Pietro, competência pode ser conceituada como conjunto de atribuições das pessoas jurídicas, órgãos e agentes, fixadas pelo direito positivo. De acordo com Di Pietro (2009), para as pessoas jurídicas políticas, a competência constaria na Constituição Federal e para os órgãos e servidores, estaria estabelecido em lei .

Nessa quadra, a Constituição Federal não distingue competência de atribuição e, menos ainda, reserva a expressão "competência" para atividades exclusivamente jurisdicionais. Pelo contrário. São diversos os dispositivos em que a norma constitucional estabelece limites ou impõe obrigações a órgãos e agentes políticos referindo-se às suas competências ${ }^{17}$. Notadamente no que tange a competências administrativas, temos referências expressas à competência da Polícia Federal (art. 22, XXII ${ }^{18}$ e art. $144, \$ 1^{\circ}$, II), das polícias rodoviária e ferroviária federais (art. 22, XXII) e do Ministério Público (art. 129, $\mathrm{VI}^{19}$ ). Com mesmo sentido de aplicação da significância à "competência", a jurisprudência do órgão intérprete da Constituição, com uso, inclusive, em verbete de súmulas, como é o caso da Súmula Vinculante n 14 , que no seu texto faz menção a "órgão de competência judiciária"20.

17 Constituição Federal arts. $5^{\circ}$, XVI; 39; 48; 58, §2; 71; 84; 87, parágrafo único; 90; 96; 102; 128, \$5, I, b; 130-A; $143, \$ 1^{\circ}$.

18 Art. 22. Compete privativamente à União legislar sobre: XXII - competência da polícia federal e das polícias rodoviária e ferroviária federais (grifo nosso).

19 Art. 129. São funções institucionais do Ministério Público: VI - expedir notificações nos procedimentos administrativos de sua competência, requisitando informações e documentos para instruí-los, na forma da lei complementar respectiva (grifo nosso).

20 Súmula Vinculante no 14: É direito do defensor, no interesse do representado, ter acesso amplo aos elementos de prova que, já documentados em procedimento investigatório realizado por órgão com competência de polícia judiciária, digam respeito ao exercício do direito de defesa. 
O direito confere a determinadas expressões ou palavras, conceitos próprios, dotados de significados específicos na linguagem jurídica. Como ensina Alfredo Castanheira Neves (2003), o direito é hermeneuticamente aberto, cujas expressões das prescrições jurídicas não têm um sentido único e fixo, admitindo sentidos contextual-pragmaticamente diferentes . Portanto, é conatural ao Direito a especificação das expressões, dando-lhes a adequada significação na linguagem jurídica. Essa a razão de se buscar as adequadas distinções para "atribuição" e "competência".

Entretanto, as definições que a doutrina fornece às expressões deverão atender às conceitualizações jurídicas já definidas e, preferencialmente, o conceito conferido não deverá ter diferentes significados dentro do mesmo sistema. Aulis Aarnio refere-se a standards de interpretação gramatical. Nesses standards uma expressão não deve ter diferentes significados em diferentes contextos a menos que se tenha justificativa suficiente para proceder-se dessa maneira , bem como não deve seu significado afastar-se do uso da linguagem comum, a menos que, também, haja justificativa suficiente para proceder-se dessa maneira ${ }^{21}$. Assim, por exemplo, o conceito de dignidade nos diversos ramos do direito não pode se afastar do significado fornecido pelo direito constitucional e, da mesma forma, não há razão que justifique admitir diferente acepção para a expressão competência no âmbito processual penal para além daquelas existentes nas demais áreas do direito.

Quando, no direito processual penal, se dá significado exclusivamente próprio, que foge aos diferentes significados dentro do próprio sistema e da linguagem comum sem que haja justificativa suficiente para atribuir essa definição, estamos nos afastando da adequada construção da linguagem jurídica, pois se afasta também dos métodos de interpretação jurídica. Não se encontra na linguagem comum e nem no sistema jurídico a restrição da expressão competência à atividade jurisdicional. Pelo contrário. Extrai-se da Constituição que as competências podem ser políticas, administrativas e jurisdicionais.

21 AARNIO, Aulis. The Rational as Reasonable - A Treatise on Legal Justification. Dordrecht: Reidel Publishing Company, 1987, p. 101: "II) an expression in a certain text should not be given a different meaning in different connections unless there is sufficient justification for proceeding in this manner. Behind this principle one can imagine that there is the idea of the consistency of regulation: if possible, the same expression in used in different connections in the same way." Em tradução livre: uma expressão em um determinado texto não deve ter um significado diferente em diferentes conexões, a menos que haja justificativa suficiente para proceder-se dessa maneira. Por trás deste princípio pode-se imaginar que não há a ideia da coerência da regulamentação: se possível, a mesma expressão usada em diferentes conexões no mesmo sentido. 
Não encontramos, em breve pesquisa doutrinária nos autores mais antigos, distinção dos termos atribuição e competência no sentido ora questionado. Helio Tornaghi (1981) e José Frederico Marques (1980) referem-se expressamente à competência administrativa ou competência para investigar. Fernando da Costa Tourinho Filho, no capítulo da persecução (investigação), redige item tratando especificamente da competência (2003, p. 194). Esclarece que a expressão "competência" é empregada em sentido vulgar, referindo-se, supostamente, ao sentido em direito administrativo, pois logo em seguida assim a define: "poder atribuído a um funcionário de tomar conhecimento de determinado assunto" (TOURINHO FILHO, 2003, p. 195). Trata, ainda, da distribuição da competência investigatória, considerando os critérios ratione loci e ratione materiae. (TOURINHO FILHO, 2003, p. 195)

Niceto Alcalá-Zamora y Castillo, ao tratar de conflito de jurisdição, estabelece três espécies de colisões, as quais denomina de "contiendas de atribución", "conflictos de jurisdicción" e "cuestiones de competencia". A mais ampla delas, a mais genérica, ou, como ele próprio refere-se, "a de maior raio", seria relativa às atribuições de diferentes poderes ou funções. A seguir, contido nesse, os conflitos relativos à jurisdição e, por fim, em esfera menor, os de competência (1972, p. 111). Reproduz-se a ilustração extraída na obra "Cuestiones de Terminologia Procesal":

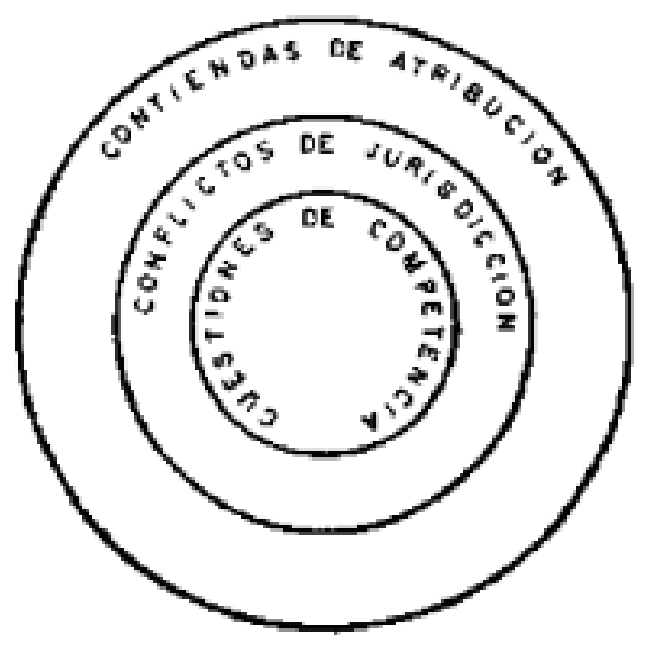

Figura 1 - Terminologia Processual 
De acordo com Alcalá-Zamora y Castillo, as atribuições estariam relacionadas às funções de diferentes órgãos ou poderes, enquanto que a competência seria a distribuição dessas funções dentro do próprio órgão (1972, p. 112). Efetivamente, nos parece a leitura mais adequada. Não se trata, portanto, de limitar o uso da expressão competência à atividade jurisdicional, mas empregá-la para as colisões decorrentes do exercício de função de um órgão com mesma atribuição.

Provavelmente, a acepção da expressão "atribuiçãa" para designar divisão de competências investigatórias também encontraria respaldo no fenômeno da colisão do exercício de funções do Ministério Público, a qual a doutrina e a jurisprudência tratam como conflito de atribuições. Cremos que o mais adequado seria dizer conflito de competências. Por dois motivos. Como parte processual, o Ministério Público exerce suas funções perante um juízo competente. Logo, quando o conflito se referir à discussão de qual das partes deve oficiar perante determinado juízo, nada mais se está a fazer do que antecipar o debate da competência jurisdicional. Significa dizer que, em última análise, o que está em jogo é a discussão da competência jurisdicional. Portanto, competência. O segundo motivo - e mais consistente - diz respeito ao caráter unitário do Ministério Público. Mesmo nas situações em que o conflito não implique na análise da competência jurisdicional, ou seja, refira-se à atividade essencialmente administrativa do Ministério Público, ainda assim, tratar-se-ia de competência. Sendo o Ministério Público instituição una e indivisível ( $\operatorname{art} .127, \$ 1^{\circ}$ ), não haveria desmembramento de atribuições, mas tão somente distribuição de competências. Competências estas, administrativas, naturalmente.

Mas não é nossa pretensão analisar a competência sob a ótica das atividades do Ministério Público, pois foge ao tema objeto da pesquisa. Limitamo-nos a referenciar a leitura do artigo de Francisco Dias Teixeira, "Conflito de atribuição e competência no Ministério Público e respectiva solução" (2009) , para quem o conflito seria de competência, e não propriamente de atribuição.

Portanto, é imperioso concluir que as expressões "atribuição" e "competência”, mesmo no campo processual, não devem ser distinguidas a partir do caráter jurisdicional da atividade exercida, já que no âmbito jurídico existem competências administrativas e competências jurisdicionais. Se o conflito se estabelece entre órgãos ou instituições que possuem funções distin- 
tas, trata-se de conflito de atribuições. Caso o conflito se dê entre entes com atribuições similares, conflito de competências. Do contrário, está-se criando significados que fogem às conexões com as demais disciplinas jurídicas sem que haja justificativa para tanto.

\subsection{COMPETÊNCIA COM CRITÉRIO DE AFERIÇÃo de VAlidAde DOS ATOS DE INVESTIGAÇÃO}

A segunda razão em admitir a expressão "competência para investigar" diz respeito à sua validade prática. Dirimir conflito de atribuições implica em reconhecer que determinado órgão possui dentre as suas funções o poder, a atribuição de executar determinada atividade e, ao mesmo tempo, afastar o exercício por parte de outro. Entretanto, se não se estabelecer o conflito, não há como avaliar a validade dos atos praticados, pois não existe no sistema jurídico a figura da "inatribuição" assim como existe da incompetência.

Giacomolli arrola dentre os limites investigatórios a vedação da dupla investigação (2011, p. 97). A Constituição confere a função investigatória às autoridades policiais. Entretanto, admite a possibilidade de o poder judiciário e o legislativo investigar de forma excepcional. Cita, também, o Ministério Público, que ainda não teve definido os limites de sua participação na investigação criminal. Para Giacomolli, esse "emaranhado de autorização legal" não pode conduzir ao fenômeno da dupla investigação, pois representa bis in idem que fragiliza as garantias constitucionais, expondo a risco de violação os direitos e liberdades do investigado. (2011, p. 98)

Nesse sentido, a pacificação do conflito de atribuições entre distintos órgãos com algumas atribuições em comum soluciona parcialmente o problema. Mas ele não fornece a solução para traçar os limites de exercício da atribuição nem delibera acerca da validade dos atos então praticados enquanto não questionado o conflito.

O sistema jurídico resolve tais ectopias pelo exame da competência. Reconhecida a atribuição do órgão para executar determinada atividade - no caso, investigar - é de se perquirir o alcance dessa atribuição verificando se o órgão possui ou não competência para a execução do ato e quais as consequências em relação ao que foi praticado, independentemente da suscitação do conflito de atribuições. 
A atividade investigatória tem a sua competência definida, em grande parte, segundo a atividade preponderante do órgão. Como a investigação criminal não é um fim em si mesma, as polícias judiciárias estão vinculadas a um respectivo órgão jurisdicional, o que determina, como regra geral, critérios ratione materiae de definição de competência administrativa investigatória. Assim, a Polícia Federal exerce a função de polícia judiciária da União ${ }^{22}$, as policiais civis estaduais, a função de polícia judiciária estadual, as polícias militares a função de polícias judiciárias da justiça militar ${ }^{23}$.

A partir dessas funções estabelecem-se as competências investigatórias segundo o critério material da competência jurisdicional. À Polícia Federal compete investigar os crimes que serão processados e julgados pela Justiça Federal (art. 109 da Constituição Federal) e pela Justiça Eleitoral (art. 121 da Constituição Federal e art. 35 da Lei no 4.737/65). Às polícias militares cabe apurar as infrações militares (art. 124 da Constituição Federal e art. $8^{\circ}$ do Decreto-Lei no 1002/69). As polícias civis estaduais têm, assim como a justiça estadual, competência residual, cabendo-lhe investigar os delitos que não sejam de competência jurisdicional eleitoral, militar ou federal.

Embora haja, como regra, a correspondência do órgão policial investigador com a justiça para a qual exerce a função de polícia judiciária, há situações em que a norma rompe essa reciprocidade.

O julgamento de crimes de tráfico de drogas é, como regra, competência da Justiça Estadual. Entretanto, se o tráfico for internacional a competência será da Justiça Federal, por estar previsto em tratado internacional do qual o Brasil é signatário (art. 109, V da CF). Não obstante, a Constituição atribui à Polícia Federal função de prevenir e reprimir o tráfico de drogas, o que lhe confere a competência para investigar tais crimes, independentemente do caráter de transnacionalidade. Trata-se, portanto, de crime de competência jurisdicional estadual enquanto que a investigação é federal, quebrando a relação polícia judiciária/justiça competente.

$\mathrm{Na}$ verdade, em decorrência de autorização expressa na Constituição ${ }^{24}$ e por força de convênio, estabelece-se uma competência investigatória concorrente entre Policia Federal e polícias civis para apuração do crime de

22 Art. 144, $\$ 1^{\circ}$, IV da Constituição Federal.

23 Art. 144, $\$ 4^{\circ}$ da Constituição Federal.

24 Art. 144, \$1º, II da Constituição Federal. 
tráfico de drogas doméstico. Esses convênios são celebrados pela União, representada pelo Ministério da Justiça, e pelo estado membro da Federação, representado pelo governador, tendo como intervenientes a Polícia Federal e as secretarias estaduais de segurança pública.

Outras situações em que a competência investigatória é transversa à competência jurisdicional são trazidas pela Lei no ${ }^{\circ} 10.446 / 02$. A lei, que regulamenta o art. $144, \$ 4^{\circ}$, I e trata das infrações penais cuja prática tenha repercussão interestadual ou internacional e exija repressão uniforme, admite a competência concorrente para a investigação dos crimes arrolados no art. $1^{\mathrm{o} 25} \mathrm{O}$ parágrafo único autoriza que a Polícia Federal investigue outros crimes, desde que atendidas duas condições: a) estejam presentes os pressupostos do caput (repercussão interestadual ou internacional e necessidade de repressão uniforme); b) que tal providência tenha sido autorizada pelo Ministro da Justiça. A leitura que se faz contrario sensu é: a Polícia Federal está impedida de investigar crimes de competência da justiça estadual que não estejam elencados na lei ou qque não sejam de repercussão interestadual ou internacional que exijam repressão uniforme. Neste caso, é fundamental que haja, ainda, autorização pelo Ministro da Justiça.

Já a limitação de competência investigatória das polícias estaduais está configurada no art. $144, \$ 1^{\circ}, I V$, o qual assevera que a Polícia Federal exerce com exclusividade as funções de polícia judiciária da União. É dizer: as polícias estaduais estão, pela Constituição, impedidas de investigar delitos cuja competência jurisdicional seja da Justiça Federal.

25 Lei n $^{\circ} 10.446 / 02$. Art. $1^{\circ}$. Na forma do inciso I do $\$ 1$ lo do art. 144 da Constituição, quando houver repercussão interestadual ou internacional que exija repressão uniforme, poderá o Departamento de Polícia Federal do Ministério da Justiça, sem prejuízo da responsabilidade dos órgãos de segurança pública arrolados no art. 144 da Constituição Federal, em especial das Polícias Militares e Civis dos Estados, proceder à investigação, dentre outras, das seguintes infrações penais:

I - seqüestro, cárcere privado e extorsão mediante seqüestro (arts. 148 e 159 do Código Penal), se o agente foi impelido por motivação política ou quando praticado em razão da função pública exercida pela vítima;

II - formação de cartel (incisos I, a, II, III e VII do art. $4^{\circ}$ da Lei no 8.137, de 27 de dezembro de 1990); e

III - relativas à violação a direitos humanos, que a República Federativa do Brasil se comprometeu a reprimir em decorrência de tratados internacionais de que seja parte; e

IV - furto, roubo ou receptação de cargas, inclusive bens e valores, transportadas em operação interestadual ou internacional, quando houver indícios da atuação de quadrilha ou bando em mais de um Estado da Federação.

V - falsificação, corrupção, adulteração ou alteração de produto destinado a fins terapêuticos ou medicinais e venda, inclusive pela internet, depósito ou distribuição do produto falsificado, corrompido, adulterado ou alterado (art. 273 do Decreto-Lei no 2.848, de 7 de dezembro de 1940 - Código Penal).

Parágrafo único. Atendidos os pressupostos do caput, o Departamento de Polícia Federal procederá à apuração de outros casos, desde que tal providência seja autorizada ou determinada pelo Ministro de Estado da Justiça. 


\section{INCOMPETÊNCIA INVESTIGATIVA}

Aqui reside um ponto ainda não enfrentado de maneira séria pela doutrina nem pela jurisprudência: quais as consequências de um crime investigado pela polícia que não tem competência para tanto? Há consequências no processo para um crime federal investigado pela polícia civil estadual? Pode a polícia militar investigar crimes comuns? A Polícia Federal teria legitimidade para requerer ou representar ao juízo estadual por medidas restritivas para apuração de delitos que lhe fogem a competência? O juízo, pelo fato de ser competente, convalidaria esses atos? Poderia a polícia civil requerer interceptação telefônica para apurar crime de contrabando ou descaminho junto à Justiça Federal? Ou essa distribuição de competências seria meramente informativa?

Cremos que já não se possa mais conceber o inquérito policial como "procedimento-dispensável-cujos-atos-não-viciam-o-processo". Admitir vícios na investigação e assepciá-los na ação penal sob o argumento de que o inquérito é uma vez que "peça meramente informativa" (RANGEL, 2008) porque dispensável ${ }^{26}$, parece-nos profanar o sistema acusatório e deixar aberta uma perigosa porta para violação de direitos.

A jurisprudência é abundante no sentido de compartimentar os vícios cometidos no inquérito como se fosse possível esterilizá-los com o oferecimento da denúncia ao se iniciar outra fase da persecução. Apenas recentemente decisões têm reconhecido a inoculação da prova obtida ilicitamente durante a investigação na ação penal ${ }^{27}$.

26 Os manuais apontam a dispensabilidade como uma das características do inquérito policial. Cremos que o melhor fosse conferir-lhe o caráter de prescindibilidade. Significa dizer: a ação penal prescinde do inquérito policial, ou seja, pode ser iniciada sem o inquérito. No entanto, uma vez instaurado ele há de estar disponível às partes, não podendo ser unilateralmente dispensado pela acusação.

27 HC 137.349 STJ, julgado em 05/04/2011. Ementa: HABEAS CORPUS. "OPERAÇÃO CASTELO DE AREIA". DENÚNCIA ANÔNIMA NÃO SUBMETIDA À INVESTIGAÇÃO PRELIMINAR. DESCONEXÃO DOS MOTIVOS DETERMINANTES DA MEDIDA CAUTELAR. QUEBRA DE SIGILO DE DADOS. OFENSA ÀS GARANTIAS CONSTITUCIONAIS. PROCEDIMENTO DE INVESTIGAÇÃO FORMAL. NECESSIDADE DE COMPROVAÇÃO DE MOTIVOS IDÔNEOS. BUSCA GENÉRICA DE DADOS. As garantias do processo penal albergadas na Constituição Federal não toleram o vício da ilegalidade mesmo que produzido em fase embrionária da persecução penal. A denúncia anônima, como bem definida pelo pensamento desta Corte, pode originar procedimentos de apuração de crime, desde que empreendida investigações preliminares e respeitados os limites impostos pelos direitos fundamentais do cidadão, o que leva a considerar imprópria a realização de medidas coercitivas absolutamente genéricas e invasivas à intimidade tendo por fundamento somente este elemento 
Nesse sentido é o questionamento de Hartmann, a qual indaga acerca dos vícios produzidos no inquérito policial e o regime a ser aplicado para o seu saneamento (HARTMANN, 2008, p. 289) . Para Hartmann, os vícios do inquérito devem ser reconhecidos, pois é procedimento que se reveste de formalidade (art. $4^{\circ}$ a 23 do CPP) e a forma é garantia ao cidadão contra os atos do Estado (HARTMANN, 2008, p. 295) . E eles não poderiam ser admitidos no processo por duas razões: suprimir uma das condições da ação por ausência de subsídios para a propositura da ação penal e por contaminar a sequência da cadeia de atos da persecução penal que foram maculados em sua base (inquérito policial) . (HARTMANN, 2008, p. 295)

Lopes Jr. e Gloeckner também enfrentam a questão com um problema a ser resolvido, reputando que as nulidades cometidas no inquérito policial são extensíveis à fase jurisdicional (LOPES JR et al., 2013, p. 333). Como salientam, "a natureza administrativa do inquérito policial não o blinda contra as garantias processuais próprias do sistema processual penal constitucional brasileiro" (LOPES JR et al., 2013, p. 338). Isso porque os princípios consagrados no art. $5^{\circ}, \mathrm{LV}$, por próprio mandamento constitucional, ampliam-se e estendem-se à fase de investigação preliminar. $\mathrm{O}$ procedimento administrativo é uma segunda espécie de procedimento cujo âmbito de aplicação desses princípios não pode ser restringido. Citam, como exemplo de nulidade produzida no inquérito policial a perícia realizada por peritos nomeados por uma autoridade policial absolutamente incompetente (ratione materiae) (LOPES JR et al., 2013, p. 350). No caso, o poder outorgado aos peritos para realização do exame, adviria de uma autoridade que não o possuía.

De fato, havemos de reconhecer que esses vícios não podem ser convalidados porque contaminam a prova. Ainda que essa prova venha (e deva), posteriormente, a ser produzida em contraditório.

Portanto, às informações, indícios e provas colhidas durante a investigação por quem não detém competência, não resta outra solução senão aplicar a mesma regra das provas obtidas de forma ilícita. Em se tratando de

de indicação da prática delituosa. A exigência de fundamentação das decisões judiciais, contida no art. 93, IX, da CR, não se compadece com justificação transversa, utilizada apenas como forma de tangenciar a verdade real e confundir a defesa dos investigados, mesmo que, ao depois, supunha-se estar imbuída dos melhores sentimentos de proteção social. Verificada a incongruência de motivação do ato judicial de deferimento de medida cautelar, in casu, de quebra de sigilo de dados, afigura-se inoportuno o juízo de proporcionalidade nele previsto como garantia de prevalência da segurança social frente ao primado da proteção do direito individual. Ordem concedida em parte, para anular o recebimento da denúncia da Ação Penal n. ${ }^{\circ}$ 2009.61.81.006881-7. 
competência, poder-se-ia dizer que o critério material para determinação da competência investigatória é absoluto, não podendo ser convalidados atos de investigação praticados por órgão incompetente.

No que tange à fixação do lugar - competência ratione loci -, o elemento territorial serve exclusivamente para organizar a distribuição de expedientes e operacionalizar a investigação. Sua inobservância não gera vício ou prejuízo à ação penal. Nem a Constituição nem a lei fixam regras de competência territorial em sede de investigação. Elas estão previstas apenas nas normativas internas dos órgãos de polícia judiciária e por isso não se constituem em normas legais de fixação de competência.

Como afirmamos anteriormente, não há a figura do delegado natural. Mesmo a redação do art. $2^{\circ}, \$ 4^{\circ}$ da Lei $n^{\circ} 12.830 / 13$, que trata de impossibilidade da avocação ou redistribuição infundada dos autos do inquérito, é suficiente para reputar a existência de um delegado natural. Logo, não há que se falar em prevenção ou algo similar no inquérito policial que possa implicar em prejuízo à formalidade da investigação ou à coleta da prova. Por conseguinte, a incompetência territorial seria mera irregularidade administrativa de natureza interna, sem efeitos na esfera penal.

Já a competência para investigação de crimes praticados por quem detém prerrogativa de foro é tema mais complexo. Como expõe Cavalcanti, a legislação da repartição de competências no critério funcional traz apenas as regras da distribuição do poder-dever de julgar, sem reportar a qualquer atividade investigativa pré-processual, "não distribuindo ou concentrando atribuições administrativas de investigação nas mãos dos órgãos judiciais" (CAVALCANTI, 2011, p. 176).

A autora refere-se ao entendimento (ou à cultura) de atribuir a investigação, nesses casos, ao próprio tribunal que fará o julgamento. Julio Mirabete sustentava que as pessoas a serem processadas e julgadas perante órgãos judiciários de superior instância não estariam sujeitas a inquérito policial, devendo a opinio delicti ser supedaneada em procedimentos disciplinares administrativos, legislativos ou judiciais ou por outras peças de informação (MIRABETE, 2003).

Cavalcanti reputa que esse entendimento teria partido da jurisprudência estabelecida no julgamento da reclamação em habeas corpus em favor 
então governador do Estado de Pernambuco, Miguel Arraes de Alencar, de relatoria do Min. Evandro Lins, em 1965, cuja ementa transcrevemos:

EMENTA: - "Habeas corpus". Competência. Não fica imune a qualquer investigação policial ou policial militar of funcionário, que tem fôro privativo por prerrogativa de função, desde que não esteja mais no exercício do cargo. Quando o funcionário está no exercício da função, à autoridade, competente para julgar, cabe, também, a investigação do fato criminoso que lhe é atribuido. Reclamação julgada procedente em parte. (HC $42.108 \mathrm{Rcl} / \mathrm{PE}$. Reclamação no Habeas Corpus. Relator: Min. Evandro Lins. Julgamento 28/04/1965.)

Certamente que num modelo processual democrático não há como se admitir que a investigação seja promovida por quem, ao final, decidirá o destino do acusado. Viola os mais comezinhos princípios do sistema acusatório. A investigação pelo julgador inebria o desapego que o juiz deve ter com a causa e fere de morte a garantia do juiz imparcial.

Por óbvio, não se trata de questionar seus valores éticos e sua retidão, mas de reconhecer o envolvimento psicológico do magistrado com os fatos que, pouco a pouco, vão sendo desvelados durante a investigação. Investigação que, ao mesmo tempo, ele a descobre e a conduz, traçando-lhe o caminho.

Exemplo que ilustra esse fenômeno é o caso Mensalão, onde o relator, então Min. Joaquim Barbosa, com incrível ingenuidade e franqueza, mostrou-se o quanto estava envolvido emocionalmente com o caso, embebido em uma "visão de túnel"28 que lhe impedia de ver e escutar seus próprios pares e a defesa dos acusados. Para Luiz Flávio Gomes (2012), Joaquim Barbosa não poderia presidir a investigação e subsequentemente ser relator na ação penal, ou seja, ao mesmo tempo ser investigador dos fatos e juiz do processo .

Para Cavalcanti, a concepção democrática e o atual modelo brasileiro admitiriam uma única diretriz procedimental para investigação desses delitos: seguir os traços paralelos à investigação policial comum, devendo ser conduzida pelos “órgãos administrativos da persecução penal (principalmen-

28 Nas ciências policiais (e também na medicina e na aeronáutica) denomina-se visão de túnel (ou visão em túnel) o foco obsessivo do agente em um único ponto, como se olhasse por meio de um tubo estreito que lhe impede de alargar o campo de visão e perceber a realidade periférica que o cerca. 
te, a Polícia Judiciária, sob controle externo do Ministério Público atuante junto ao Tribunal)". Tal como ocorre nos casos comuns, a judicialização da investigação seria apenas para atribuir a um relator o papel de juiz de garantias. (CAVALCANTI, 2011)

Mesmo que ainda exista um ranço inquisidor nas investigações por prerrogativa de função, onde o relator exerce suas funções para além de juiz garantidor, a jurisprudência do STF é no sentido de admitir o inquérito policial para investigação de agentes com prerrogativa e afastar a participação do relator da função investigativa:

EMENTA: I. STF: competência originária: habeas corpus contra decisão individual de ministro de tribunal superior, não obstante susceptivel de agravo. II. Foro por prerrogativa de função: inquérito policial. 1. A competência penal originária por prerrogativa não desloca por si só para o tribunal respectivo as funções de polícia judiciária. 2. A remessa do inquérito policial em curso ao tribunal competente para a eventual ação penal e sua imediata distribuição a um relator não faz deste "autoridade investigadora", mas apenas lhe comete as funçôes, jurisdicionais ou não, ordinariamente conferidas ao juiz de primeiro grau, na fase pré-processual das investigações. III. Ministério Público: iniciativa privativa da ação penal, da qual decorrem (1) a irrecusabilidade do pedido de arquivamento de inquérito policial fundado na falta de base empirica para a denúncia, quando formulado pelo Procurador-Geral ou por Subprocurador- Geral a quem delegada, nos termos da lei, a atuação no caso e também (2) por imperativo do princípio acusatório, a impossibilidade de o juiz determinar de ofício novas diligências de investigação no inquérito cujo arquivamento é requerido.

Portanto, é inadmissível a presidência da investigação por parte do juiz relator do processo. Aliás, sequer era pertinente que, nos órgãos colegiados, o relator do inquérito - que exerce a função de juiz garantidor - fosse relator, também, do processo.

\section{DeMAIS Órgãos COM COMPETÊNCIA PARA INVESTIGAR}

Além da polícia judiciária, outros órgãos têm, como função atípica, a atribuição para produzir investigação de natureza criminal. É o caso das Comissões Parlamentares (CPIs) e da magistratura e Ministério Público nas investigações interna corporis. São funções atípicas, que geram uma compe- 
tência excepcional. As Comissões Parlamentares possuem, materialmente, uma competência ampla, sendo suficiente para a instalação da Comissão a aprovação de $2 / 3$ dos membros da Casa. Uma vez instalada, o objeto da investigação ficará restrito ao fato (ou fatos) caracterizado no requerimento da constituição da Comissão (SANDOVAL, 2014). Por outro lado, o exercício da investigação é temporalmente limitado, eis que se trata de espécie de Comissão Parlamentar temporária.

A investigação criminal produzida pela magistratura tem a competência limitada à investigação de fatos em que a suspeição de autoria do crime recaia sobre outro juiz, pois é prerrogativa do magistrado que a investigação seja promovida pelo respectivo Tribunal, nos termos do art. 33, parágrafo único da Lei Complementar n 35/79 (Lei Orgânica da Magistratura Nacional).

Mesma prerrogativa possuem os membros do Ministério Público, assegurada pela Lei no 8.625/93 (Lei Orgânica Nacional do Ministério Público) e Lei Complementar no 75/93 (Lei Orgânica do Ministério Público da União). Da mesma forma, elas estabelecem competência às respectivas procuradorias-gerais para promover a investigação criminal de seus membros.

Dúvida ainda paira em relação às investigações pelo Ministério Público em crimes outros que não envolvam seus membros. Não pretendemos, aqui, enfrentar essa questão. Mas, pelas razóes expostas, há de se concluir que a competência investigatória do Ministério Público terá sempre natureza excepcional, pois se trata de atividade atípica e, por isso, haveria de ser confinada a situações específicas, com autorização, limites e controles expressamente estabelecidos em lei. Diversamente da divisão da divisão de competências estabelecida pela Constituição e pela Lei às policias, a investigação pelo Ministério Público nos demais casos não encontra respaldo legal ou constitucional, mas decorre exclusivamente de interpretação jurisprudencial (ainda que pelo Pretório Excelso), em manifesto amorfismo jurídico. Portanto, a prática de atos que caracterizam a investigação criminal, tais como oitivas, interrogatórios, perícia, vigilância, informes, execução de medidas investigativas que dependam de autorização judicial (interceptação telefônica, busca e apreensão, por exemplo), entre outros, por parte do Ministério Público devem ser reputados como ilícitos por violarem regras de competência investigatória.

O fato de o Código de Processo Penal admitir o oferecimento de denúncia sem inquérito policial (prescindibilidade do inquérito policial) não 
pode se constituir em uma carta coringa que autoriza o desrespeito às regras de forma e competência da investigação. A leitura do art. 12 do CPP deve ser feita em harmonia com os demais dispositivos do CPP e com sistema acusatório. Do contrário, redunda em uma carta branca que esvazia as garantias do acusado e, novamente, converte a investigação criminal em procedimento medievo, sigiloso, sem prazo e passível de ser realizado por qualquer ente, até mesmo alheio às atividades estatais.

Há crimes que dispensam investigação. Daí o caráter de prescindibilidade da investigação criminal. Por vezes, a notícia crime já tem os elementos indiciários suficientes para o oferecimento da denúncia. Por essa razão, o CPP autoriza que o processo seja iniciado sem inquérito policial. Situação bem diversa, admitir uma investigação criminal informal e paralela. Se for necessário investigar um crime, a investigação somente pode se dar por meio de inquérito policial, que é o procedimento hábil para tanto.

\section{Conclusão Articulada}

1. A investigação preliminar, de natureza criminal, deve ser realizada obedecendo forma e rito estabelecido em lei, como condição de estar em harmonia com o sistema acusatório e democrático de persecução penal.

2. Fornecer o significado correto às expressões "atribuição" e "competência” tem implicação de natureza prática no sistema processual. A distinção entre atribuição e competência trazida nos manuais de processo penal, considerando competência para atividade jurisdicional e atribuição para atividade administrativa, não encontra suporte na linguagem jurídica, eis que foge dos standards de intepretação gramatical, criando significados diferentes daqueles já existentes no sistema jurídico sem justificativa para tanto.

3. O sistema jurídico, de forma geral, considera "atribuição" as funções atribuídas a um órgão, enquanto que competência seria a esfera, a área que delimita o exercício da atribuição por parte desse agente ou órgão. Assim, seria adequado falar em conflito de atribuição apenas quando ele se der entre entes estatais que possuem funções típicas distintas (judiciário e Ministério Público, por exemplo). Já o conflito de competência corresponderia às repartições da atri- 
buição dentro do mesmo ente ou entre entes com caráter unitário ou que possuem funções típicas idênticas ou similares, como é o caso v.g., da Justiça Federal e Eleitoral ou estadual, da Polícia Federal e polícias civis, ou do Ministério Público Federal e Ministério Público Estadual.

4. As polícias judiciárias possuem em comum a atribuição para investigar e delimitação desse exercício se dá mediante análise da respectiva competência administrativa para tanto, estabelecida na Constituição.

5. Competência para investigar e competência para julgar não se confundem. Embora a Polícia Federal exerça a função de polícia judiciária da Justiça Federal e as polícias civis a função de polícia judiciária das respectivas justiças estaduais, essa simetria não é integral. Há crimes que são processados pela justiça estadual mas investigados pela Polícia Federal, como é o caso do tráfico de drogas sem transnacionalidade ou dos crimes previstos na Lei ${ }^{\circ}$ 10.446/02.

6. A competência investigativa da Polícia Federal consta no art. 144, $\$ 1^{\circ}$ da Constituição Federal. A Constituição admite que esse rol seja estendido, desde que a ampliação se dê por lei $\left(\operatorname{art.} 144, \$ 1^{\circ}, \mathrm{I}\right)$ e limitada a infrações cuja prática tenha repercussão interestadual ou internacional e exija repressão uniforme. A lei no 10.446/02 regulamentou a matéria. Investigações criminais realizadas pela Polícia Federal para além das matérias aí previstas não encontram respaldo legal ou constitucional.

7. A competência investigativa das polícias civis é residual, mas limitada à função de polícia judiciária estadual. A Constituição confere à Polícia Federal a exclusividade do exercício da função de polícia judiciária da União (art. 144, $\$ 1^{\circ}, \mathrm{IV}$ ), assim como às polícias militares a apuração de crimes militares (art. 144, $\$ 4^{\circ}$ ). Apurações de crimes pelas polícias civis para além daqueles que são de competência da justiça a qual está vinculada não encontram respaldo legal ou constitucional

8. A competência investigativa é concorrente entre Polícia Federal e polícias civis nos crimes de tráfico de drogas não transnacional e nas infrações previstas na Lei no 10.446/02. 
9. Essas definições indicam que o critério de definição de competência investigativa em razão da matéria é absoluto, não admitindo prorrogação ou delegação.

10. Investigações que não obedecem os critérios de competência investigatória em razão da matéria podem implicar em nulidade à prova produzida, porque obtida de forma ilícita.

11. A incompetência por critérios territoriais não traz prejuízos a ação penal e, por isso, não geraria nulidade.

12. Nem a Constituição nem a lei estabeleceram regras de competência para investigação de crimes em que há foro por prerrogativa de função. Nesse caso, por ausência previsão expressa, competência para investigar deve seguir o modelo geral, traçando paralelismo com crime comum: a investigação deve ser realizada respectiva polícia judiciária.

13. Poder Legislativo, Poder Judiciário e Ministério Público possuem, entre suas atribuições, a função atípica de investigar. Assim, a lei lhes confere competência excepcional para investigação de determinados delitos. A investigação pelo Poder Legislativa é materialmente ampla mas temporalmente limitada. A investigação por parte do Poder Judiciário ou do Ministério Público que não envolvam membros de seus quadros não encontra respaldo legal ou constitucional.

14. É inevitável concluir que delimitar a atividade investigatória a partir da análise das competências é, mais que uma adequação semântica, a congruência da investigação preliminar ao sistema processual democrático, para além da etiquetação de atos estanques, superando-se a dicotomia inquisitivo/acusatório. A natureza inquisitiva de determinados atos da investigação não pode furtar o caráter acusatório da persecução penal. Apenas a investigação formal (forma prevista em lei), promovida por agente ou órgão que detém a competência legal e a exerce mediante controle externo em tempo real está alinhada ao modelo democrático que se pretende do processo penal. 
Alessandro Maciel Lopes

Delegado de Polícia Federal. Professor de Direito Processual Penal na Urcamp. Mestrando em Ciências Criminais na PUC/RS. Especialista em Direito Processual

Penal pela Escola Paulista da Magistratura.

E-MAIL: ALESSANDRO.AML@DPF.GOV.BR

\section{Competence in Preliminary Investigation: No LOSSES TO PROCESS?}

\section{ABSTRACT}

It is a brief research to examine the appropriateness of the use of the term "competence" for the preliminary investigation activity and its practical effects on the criminal action. It intends to analyze the validity of evidence from the agent's ability to produce investigation and formalization of his actions.

KEYwORDS: Preliminary Investigation. Competence. Assignment. Validity. Evidences

\section{Competencia en la Investigación Preliminar: HAY PREJUICIO PARA EL PROCESO?}

\section{RESUMEN}

Se trata de pesquisa para examinar la conveniencia de la utilización del término "competencia" en la actividad de investigación preliminar y sus efectos prácticos sobre la acción penal. Tiene la intención de analizar la validez de la evidencia desde la capacidad del agente que produce la investigación y la formalización de sus acciones.

Palabras Clave: Investigación preliminar. Competencia. Asignación. Validez. Prueba. 


\section{REFERÊNCIAS}

AARNIO, Aulis. The Rational as Rasonable - A Treatise on Legal Justification. Dordrecht: Reidel Publishing Company, 1987.

ALCALÁ-ZAMORA Y CASTILLO, Niceto. Cuestiones de terminología procesal. México: Universidad Nacional Autonoma de México, 1972.

ARAÚJO, Moacir Martini de. O Princípio do Delegado Natural Com Efetivação do Estado Democrático de Direito. Revista Brasileira de Ciências Policiais, Vol 3, p. 27-41, jan/jun 2012.

AVILA, Humberto. Teoria dos princípios - da definição à aplicação dos princípios jurídicos. São Paulo: Malheiros Editores, 2012.

CAPEZ, Fernando. Curso de Direito Penal I. 16. ed. São Paulo: Editora Saraiva, 2012.

CAVALCANTI, Danielle Souza de Andrade e Silva. A Investigação preliminar nos delitos de competência originária de tribunais. Rio de Janeiro: Lumen Juris, 2011.

DI PIETRO, Maria Sylvia Zanella. Direito administrativo. São Paulo: Atlas, 2009.

DROMI, Roberto. Derecho Administrativo. 10 a edicion. Buenos Aires Madrid: Ciudad Argentina, 2004.

GIACOMOLLI, Nereu. A fase preliminar do processo penal. Crises, misérias e novas metodologias investigatórias. Rio de Janeiro: Lumen Juris, 2011.

GOMES, Luiz Flavio. Barbosa pode ser investigador e o juiz do Mensalão? Disponível em: http://www.conjur.com.br/2012ago-08/luiz-flavio-gomes-joaquim-barbosa-investigador-juizmensalao. Acesso em 23/09/2014.

GOMES, Luiz Flavio. Nova lei de falências e suas repercussões criminais. Disponível em http://www.rkladvocacia.com/arquivos/artigos/ art_srt_arquivo20080731130157.pdf. Acesso em 08/07/14.

GOMES, Rodrigo Carneiro. As prerrogativas processuais na investigação policial. Revista CEJ, Brasília, Ano XII, n. 41, p. 4758, abr./jun. 2008. 
HARTMANN, Erica de Oliveira. Nulidade no inquérito. Revista Raízes Jurídicas, Curitiba, v. 4, n. 1, p. 289, jan. a jun/2008.

LOPES JR, Aury; GLOECKNER, Ricardo Jacobsen. Investigação preliminar no Processo Penal. São Paulo: Saraiva, 2013.

MARQUES, José Frederico. Tratado de Direito Processual Penal, vol. I. Saraiva: São Paulo, 1980.

MIRABETE, Julio Fabbrini. Processo Penal. 14a edição. São Paulo: Atlas, 2003.

NEVES, A. Castanheira. $\mathbf{O}$ actual problema metodológico da interpretação jurídica - I. Coimbra: Coimbra Editora, 2003.

NUCCI, Guilherme de Souza. Manual de processo penal e execução penal. $11^{\mathrm{a}}$ ed. São Paulo: Forense, 2014.

OLIVEIRA, Eugenio Pacelli de. Curso de Processo Penal. 15 a ed. Rio de Janeiro: Lumen Juris, 2011.

RANGEL, Paulo. Direito processual penal. $15^{a}$ edição. Rio de Janeiro: Lumen Juris, 2008.

SANDOVAL, Ovídio Rocha Barros. A CPI da Petrobrás e a pretendida amplitude defendida pela Presidência do Senado Federal. Disponível em: <http://www.migalhas.com.br/ dePeso/16,MI199871,11049-A+CPI+da+Petrobras+e+a+pretendi da+amplitude+defendida+pela >. Acesso em 14 out. 2014.

SILVA, Eduardo Pereira. Prerrogativa de foro no inquérito policial. Revista CEJ, Brasília, n. 36, p. 6-13, jan./mar. 2007.

STRECK, Lenio Luiz; OLIVEIRA, Rafael Tomaz de. O que é isto - as garantias processuais. Porto Alegre: Livraria do Advogado, 2012. E-book.

STRECK, Lenio Luiz. O pan-principiologismo e o sorriso do lagarto. Disponível em: http://www.conjur.com.br/2012-mar-22/sensoincomum-pan-principiologismo-sorriso-lagarto. Acesso em 11/07/14.

TAVORA, Nestor; ALENCAR, Rosmar Rodrigues. Curso de Direito Processual Penal. Salvador: Jus Podivm, 2012.

TEIXEIRA, Francisco Dias. Conflito de atribuição e competência no 
Ministério Público e respectiva solução. Boletim Científico da Escola Superior do Ministério Público da União, Brasília, n ${ }^{\circ}$ 30/31, janeiro/dezembro 2009.

TORNAGHI, Hélio. Curso de Processo Penal. Vol. I. $2^{a}$ ed. São Paulo: Saraiva, 1981.

TOURINHO FILHO, Fernando da Costa. Processo Penal. Vol. I. São Paulo: Saraiva, 2003.

VALENTE, Manuel Monteiro Guedes. Teoria Geral do Direito Policial. Coimbra: Almedina, 2009.

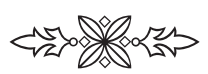

